\title{
Trace Metal Analysis of Karuk Traditional Foods in the Klamath River
}

\author{
Kari Marie Norgaard ${ }^{1}$, Spenser Meeks ${ }^{2}$, Brice Crayne ${ }^{2}$, Frank Dunnivant ${ }^{2 *}$ \\ ${ }^{1}$ Environmental Studies Program, 5223 University of Oregon, Eugene, USA; ${ }^{2}$ Chemistry Department, Whitman College, Walla \\ Walla, USA. \\ Email: *dunnivfm@whitman.edu
}

Received January $17^{\text {th }}, 2013$; revised February $18^{\text {th }}, 2013$; accepted March $20^{\text {th }}, 2013$

Copyright (C) 2013 Kari Marie Norgaard et al. This is an open access article distributed under the Creative Commons Attribution License, which permits unrestricted use, distribution, and reproduction in any medium, provided the original work is properly cited.

\begin{abstract}
This study evaluates the presence of trace metals in Klamath River water and three important Karuk traditional foods: freshwater mussels (Gonidea angulata), Chinook Salmon (Oncorhynchus tshawytscha) and Rainbow Trout (Oncorhynchus mykiss). Samples of these traditional foods together with water samples were collected from the Klamath River and measured for the total chromium (Chromium), cobalt $(\mathrm{Co})$, copper $(\mathrm{Cu})$, cadmium $(\mathrm{Cd})$, tin $(\mathrm{Sn})$, and lead $(\mathrm{Pb})$ by inductively coupled plasma-mass spectrometry (ICP-MS). We found that cultural-use species in the Klamath and its tributaries are accumulating higher levels of lead, cadmium and tin downstream of a known Superfund site. Neither water, fish, nor mussel samples exceeded maximum intake levels of metal doses mandated by state or federal agencies for consumption intakes of $1.4 \mathrm{~L}$ per day of water, $0.5 \mathrm{~kg}$ per meal per day for fish, and $0.043 \mathrm{~kg}$ per meal for 30 meals per year ${ }^{1}$.
\end{abstract}

Keywords: Trace Metals; Metals Analysis; Klamath River

\section{Introduction}

The Klamath River historically supplied an abundance of natural productivity that in turn supported culturally rich human activity [2]. More recently the Klamath region has been the site of significant conflict over water allocation, endangered species and the presence of multiple dams that are now under consideration for removal [3-6]. The Klamath River Basin is home to the three largest Native American tribes in the State of California and the largest tribe in Oregon. The middle Klamath Basin is the ancestral territory for the Karuk Tribe of California. For Karuk people cultural and subsistence uses of riverine species are at the heart of culture, social structure, spiritual life, and physical health, and form the basis of informal economic activity [7-9]. Yet today, impaired water quality compromises each of these concerns $[8,10]$.

This study evaluates the presence of trace metals in Klamath River water and three important Karuk tradi-

\footnotetext{
*Corresponding author.

${ }^{1}$ Traditional pre-contact Karuk salmon consumption was approximately $0.25 \mathrm{~kg}$ /day [1]. Current fish consumption is constrained by availability, however many tribal members would like to be consuming an average of $300.5 \mathrm{~kg}$ meals per year and some tribal members might in fact be doing so.
}

tional foods: freshwater mussels (Gonidea angulata), Chinook Salmon (Oncorhynchus tshawytscha) and Rainbow Trout (Oncorhynchus mykiss). The contamination of Native foods is largely invisible both because state and federal standards presume lower levels of consumption and recreational rather than subsistence consumption, and because many of the food species consumed by Native people are simply not studied for contamination. On the Klamath, riverine organisms such as salmon and freshwater mussels are important traditional foods and cultural use species for the Karuk Tribe [7-9].

Trace metals, unlike more synthetic organic pollutants, can originate from both natural sources, such as bedrock or forest fires, and anthropogenic sources, including industrial activity, mining and agriculture [11-14]. Possible sources of trace metals in the Klamath River Basin include historical and current mining operations, forest fires, and agriculture. Trace metals are particularly likely to accumulate in salmon species while feeding in the oceans [12,15], while organisms such as Rainbow Trout and freshwater mussels spend their entire lives in river systems which may contain metals from mining activities, forest fires, and agriculture [16]. Freshwater mussels filter water through their gills and therefore bioaccumu- 
late toxins.

Two EPA listed Superfund sites in the Klamath River watershed are examples of historic mining as a possible vector: Grey Eagle Mine (EPA\#: CAD980638860) and Celtor Chemical Works (EPA\#: CAD000629923). Grey Eagle Mine was a copper mine, last operated during World War II, and Celtor Chemical Works was an ore processing plant for copper, zinc and precious metal extraction from 1958 to 1962 [17]. Celtor Chemical Works, on the other hand, has been completely remediated, and in 2006 EPA scientists formally certified that the site is ready for unrestricted use [18].

A third potential vector of contamination is present-day suction dredge mining on the Klamath ${ }^{2}$. Suction dredging has been shown to release trace inorganic metals associated with gold-bearing minerals-such as copper, arsenic, lead and zinc [19]. Besides disturbing silt and changing the shape of the river, there is evidence that dredging mobilizes trace metals in the water column by resuspension of polluted sediments and subsequent desorption of metal pollutants, leading to their subsequent accumulation in the biota in the immediate area $[20,21]$.

To what extent are trace metals entering the food web within the Klamath Basin? Does trace metal contamination pose safety threats for Karuk consumption of trout, salmon or freshwater mussels in the Klamath River? We analyzed concentrations of chromium, cobalt, copper, cadmium, tin and lead in three widely consumed Karuk cultural use species. This study used a unique and innovative sampling design that allowed for simultaneous evaluation of both a range of traditional foods and assessment of potential source vectors. Trout tissue sampling was used to evaluate trace metal levels in specific tributaries with known potential point sources and to distinguish between marine and freshwater sources (trout remain in the riverine system). Levels of trace metals have been shown to accumulate in salmon during the portion of their lives spent out in the ocean [15], thus, sampling of salmon tissue allowed for evaluation of marine sources of contamination. Finally, freshwater mussels are long-lived, sedentary filter feeders that are included in the traditional diet. Freshwater mussel tissue sampling was used to evaluate long-term trace metal in the main-stem of the Klamath River.

\section{Materials and Methods}

\subsection{Study Site}

The Klamath originates in south-central Oregon, east of the Cascade Range, flows for 423 kilometers crossing the California border and empties into the Pacific Ocean 26 kilometers south of Crescent City. The Klamath River

\footnotetext{
${ }^{2}$ As of 2009 the State of California has issued a moratorium on suction
} dredge mining in order to allow for a process of environmental review. watershed drains about 12,900 $\mathrm{km}^{2}$ in Oregon and 25,900 $\mathrm{km}^{2}$ in California.

\subsection{Sample Collection and Preparation}

The sampling scheme took advantage of the unique life histories of three traditional Karuk food species to simultaneously evaluate the contamination of these foods, whether trace metals are entering tribal diets and potential source vectors. Sample sites ranged over the lower portion of the Klamath River starting at Copco 2 Dam and extending down to the mouth of the river (refer to Figure 1 for sample locations), covering $312 \mathrm{~km}$ of the river.

\subsubsection{Water Samples}

In order to test for trace metal concentrations in the main branch of the Klamath River and/or any point sources that may occur along its length, water samples were taken over a one-week period (July, 2007) from sites 1-15 (Figure 1). Water sampling sites were spaced approximately $20 \mathrm{~km}$ apart from one another on the main branch of the Klamath River to determine if any point sources are introducing trace metals to the river system. The farthest site upstream (site 1) was just below Copco 2 Dam (312 km upstream) and the farthest downstream (site 15) was at Klamath Glen about $10 \mathrm{~km}$ from the mouth of the river. Three water samples, $\sim 100 \mathrm{ml}$ each, were collected from each site in $50-\mathrm{mL}$ polypropylene bottles, and $1.00 \mathrm{~mL}$ of concentrated ultra-pure $\mathrm{HNO}_{3}$ was added for preservation. Each sample was filtered through a $0.4-\mu \mathrm{m}$ polysulfone disposable syringe filter (Whatman) prior to analysis to yield dissolved metal concentrations.

\subsubsection{Freshwater Mussels}

As sedentary, filter-feeding organisms, bivalves have been shown to be a reliable keystone species for identifying trace-metal contamination [21]. Freshwater mussels (Gonedia angulata) in the Klamath River exist in adequate abundance to allow for sampling for trace metals. Samples of freshwater mussels and river water were taken at sites to evaluate whether mussels have been selectively filtering metals from river water. Mussel samples were collected at all water sampling sites that had an established healthy population of mussels living near the water collection site. Whole mussel samples were taken at sites 2-5, and 8-12 (Figure 1). Samples were double bagged in Ziploc ${ }^{\circledR}$ plastic bags and kept on ice until arrival at Whitman College (Walla Walla, WA, USA) where they were then frozen until processed. Processing mussels for ICP-MS analysis required first chemically digesting the samples by removing the mussel tissue, blending it with a small amount of 3 percent ultra-pure $\mathrm{HNO}_{3}$, weighing out $\sim 1.1 \mathrm{~g}$ of the slurry, adding $1.00 \mathrm{~mL}$ 


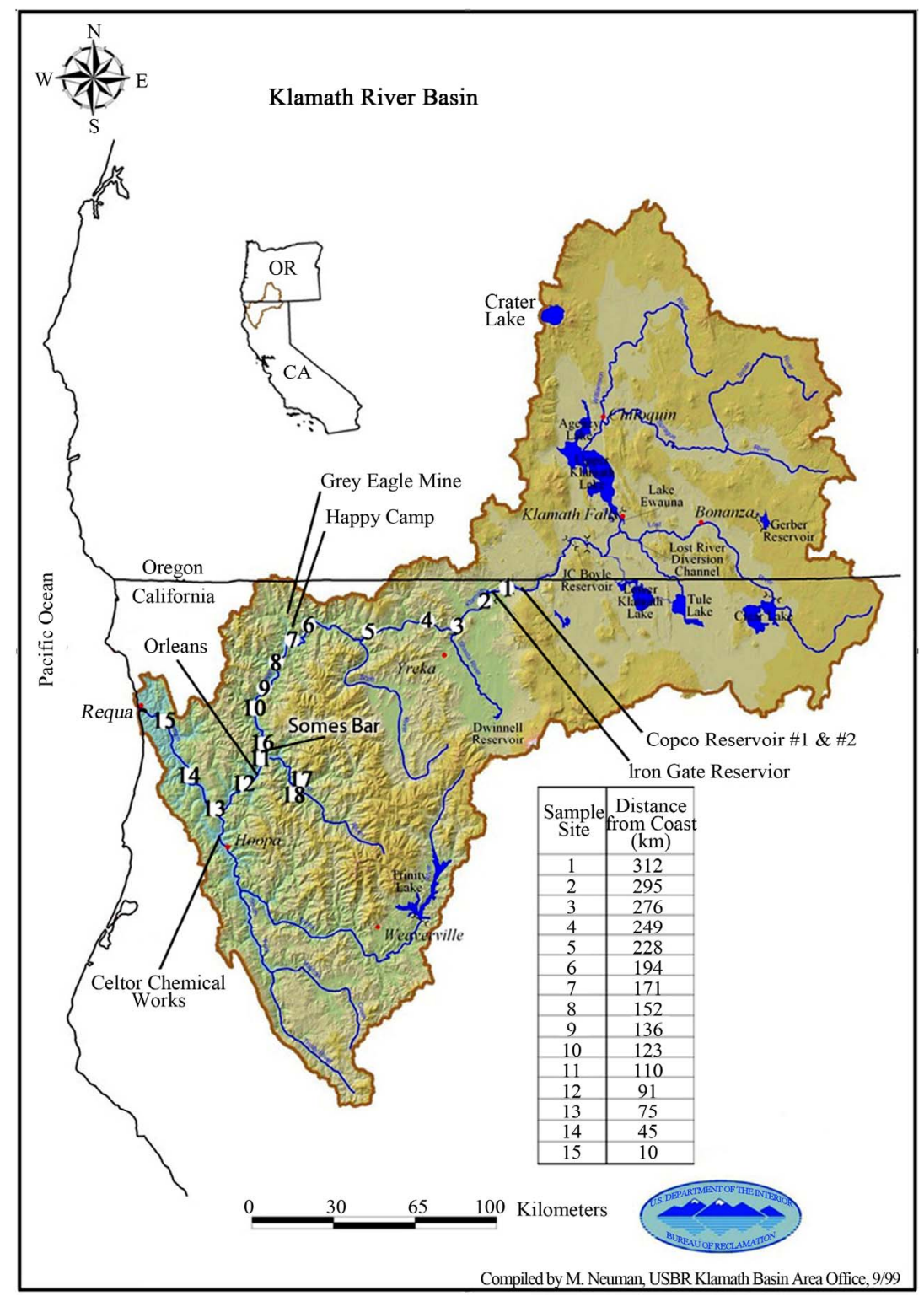

Figure 1. Map of the Klamath River Basin with numbered sampling sites.

of concentrated $\mathrm{HNO}_{3}$ as well as $4.00 \mathrm{~mL}$ of concentrated ultra-pure $\mathrm{H}_{2} \mathrm{SO}_{4}$, and allowing samples to digest overnight at room temperature. After the samples were fully digested into a liquid state they were diluted to $50.00 \mathrm{~mL}$ in a Class A volumetric flask using 3 percent ultra-pure $\mathrm{HNO}_{3}$, stored in a $150 \mathrm{~mL}$ plastic bottle, and then $\sim 10 \mathrm{~mL}$ of the digested solution were filtered through a $0.20-\mu \mathrm{m}$ Teflon or nylon-fiber filter cartridge into $15 \mathrm{~mL}$ polypropylene vials for analysis on an ICPMS. Mussel preparation for analysis was done in accordance with standards established by the American Society for Testing and Materials [22].

\subsubsection{Rainbow Trout}

Rainbow Trout (Oncorhynchus mykiss) were collected from specific tributary creeks with suspected contaminants. Rainbow Trout sampling sites were located on three tributaries of the Klamath River: Indian Creek (site $7 ; 171 \mathrm{~km}$ from the coast) and the North and South Forks of the Salmon River (sites 17 and 18 at approximately $140 \mathrm{~km}$ from the coast; refer to Figure 1). The Indian Creek location is downriver of an untreated EPA Superfund site, while the North and South forks of the Salmon River were subject to extensive historical placer gold mining and recent suction dredge activity (refer to Figure 1). Five trout were harvested from each of the three sites. Fish were double bagged in Ziploc plastic bags and kept on ice until arrival at Whitman College where they were then frozen until processed. In order to process the fish $\sim 0.5 \mathrm{~g}$ of muscle was removed from beside a pecto- 
ral fin, placed in a $15-\mathrm{mL}$ plastic vial, and $1.00 \mathrm{~mL}$ of concentrated ultra-pure $\mathrm{HNO}_{3}$ as well as $4.00 \mathrm{~mL}$ of ultra-pure $\mathrm{H}_{2} \mathrm{SO}_{4}$ were added. Samples were left to digest for several hours at room temperature, agitated once and then left to finish digesting until the following day. The remaining acidic liquid was then diluted to $100.0 \mathrm{~mL}$ in a glass Class A volumetric flask using double deionized water and stored in a $150 \mathrm{~mL}$ plastic bottle. Finally, $\sim 10$ $\mathrm{mL}$ were filtered through a $0.4-\mu \mathrm{m}$ polysulfone disposable syringe filter (Whatman) into a $15 \mathrm{~mL}$ polypropylene vial until analyzed on ICP-MS.

\subsubsection{Chinook Salmon}

Returning adult Chinook Salmon (Oncorhynchus tshawytscha) were sampled primarily from the Klamath River near Somes Bar, California to determine if salmon were accumulating unsafe levels of trace metals while living in the ocean. Twenty-seven fish were collected at the mouth of the Klamath River (site 15; $10 \mathrm{~km}$ from the coast) and near Somes Bar, CA (site 16; approximately $110 \mathrm{~km}$ from the coast). Sample collection, preparation and other procedures were identical to those described above for Rainbow Trout.

\subsection{Chemicals Used in Analysis}

All standards and spikes were made using commercially available atomic absorption-inductive couple plasma spectrometry $1000 \mathrm{mg} / \mathrm{L}$ metal standards (RICCA Chemical Company) in varying degrees of ultra-pure nitric acid for preservation. All acids used in this study were either concentrated nitric acid, $\mathrm{HNO}_{3}$ (ultra-pure Omni-trace, EDM Chemicals) or concentrated sulfuric acid, $\mathrm{H}_{2} \mathrm{SO}_{4}$ (ultra-pure Aristar Plus, VWR Scientific Products). All water used for experimental purposes was double deionized $(<18$ michromiumo Ohm conductivity) (Millipore Milli-Q system). While trace mercury analysis would be of interest to this project, cold vapor atomic fluorescence spectrometry, with a detection limit of $0.04 \mathrm{ng} / \mathrm{L}$, is a more appropriate method than ICP-MS. Hence, mercury analysis was not included in this investigation.

\subsection{Trace Metal Analysis on ICP-MS}

An Agilent 7500ce ICP mass spectrometer was used to determine trace metal content in water, mussel and fish samples. All samples were analyzed using the same parameters. Metal analysis included: chromium, cobalt, copper, cadmium, tin, and lead. External calibration was performed using standards ranging from $5 \mathrm{ng} / \mathrm{L}$ to 1 $\mathrm{mg} / \mathrm{L}$. Internal standard metals (bismuth (Bi), gallium $(\mathrm{Ga})$, and indium (In)) at $50 \mu \mathrm{g} / \mathrm{L}$ were also used during analysis and calibration to ensure low detection limits and account for quadrupole tuning drift. Each detection limit was based on the lowest external standard in the least squares regression calibration line.

\subsection{General Protocols/Quality Control/Quality Assurance}

Procedural/reagent blanks were run to determine lower detection limits based on the lowest external calibration standard that fit onto the linear least squares regression line. Detection limits for water, mussel tissue, and fish tissue are given in Table 1.

Approximately every fifth samples was spiked near the middle of the calibration line for each metal. Spikes were performed with water, mussel, and fish samples. All samples were analyzed in triplicate and spiked to test spike recoveries. Water samples were spiked directly into the acidified sample while tissue samples were spiked immediately after tissue homogenization and then samples were treated as a normal tissue sample and taken through the entire digestion, dilution, and ICP procedure. Multiple blanks consisting of 3.0 percent ultra-pure $\mathrm{HNO}_{3}$ were run on the ICP and checked between each sample to ensure that no cross-contamination occurred between samples and standards. Mussel samples were digested whole without the removal of their digestive system which could have slightly evaluated the trace metal concentrations due to the inclusion of sediment in the gut. Water samples were spiked at $100 \mu \mathrm{g} / \mathrm{L}$, all fish at $50 \mu \mathrm{g} / \mathrm{kg}$, and mussels at 200,22 and $3.5 \mu \mathrm{g} / \mathrm{kg}$. Generally, good and reproducible spike recoveries were obtained for all metals and are shown in Table 2.

Risk calculations for oral exposure to contaminants in water, shellfish and fish were performed following the procedure outlined by [23]. Risk calculations for water were calculated with

$$
\begin{aligned}
& \text { Intake from drinking water }(\mu \mathrm{g} / \mathrm{kg} \cdot \text { day }) \\
& =\frac{(\mathrm{CW})(\mathrm{IR})(\mathrm{EF})(\mathrm{ED})}{(\mathrm{BW})(\mathrm{AT})}
\end{aligned}
$$

where $\mathrm{CW}$ is the measured metal concentration in the Kalmath River Water in $\mu \mathrm{g} / \mathrm{kg}$, IR is the ingestion rate fixed at $1.4 \mathrm{~L} /$ day, $E F$ is the exposure frequency fixed at 365 meals or days per year, ED is the exposure duration fixed at 70 years, BW is the human body weight fixed at $70 \mathrm{~kg}$, and AT is the average time of exposure fixed at

Table 1. ICP detection limits for all metals studied here.

\begin{tabular}{ccccccc}
\hline $\begin{array}{c}\text { Sample } \\
\text { Matrix }\end{array}$ & Chromium & Cobalt & Copper & Cadmium & Tin & Lead \\
\hline $\begin{array}{c}\text { Water } \\
(\mu \mathrm{g} / \mathrm{L})\end{array}$ & 0.100 & 0.100 & 1.00 & 0.0100 & 0.100 & 1.00 \\
$\begin{array}{c}\text { Mussel } \\
(\mu \mathrm{g} / \mathrm{kg})\end{array}$ & 5.00 & 5.00 & 50.0 & 0.500 & 5.00 & 50.0 \\
$\begin{array}{c}\text { Fish } \\
(\mu \mathrm{g} / \mathrm{kg})\end{array}$ & 20.0 & 20.0 & 200.0 & 2.00 & 20.0 & 200.0 \\
\hline
\end{tabular}


25,550 days (70 years). Risk calculations for consumption of mussel and fish tissue were calculated with

Chronic Daily Intake (CDI) from eating $(\mu \mathrm{g} / \mathrm{kg} \cdot$ day $)$

$$
=\frac{(\mathrm{CM})(\mathrm{IR})(\mathrm{FI})(\mathrm{EF})(\mathrm{ED})}{(\mathrm{BW})(\mathrm{AT})}
$$

where $\mathrm{CM}$ is the measured metal concentration in mussel or fish tissue in $\mu \mathrm{g} / \mathrm{kg}$, IR is the ingestion rate of food fixed at $0.043 \mathrm{~kg} / \mathrm{meal}$ for mussel or $0.500 \mathrm{~kg} / \mathrm{meal}$ for fish, FI is the fraction of intake from the tested source fixed at 1 (for 100 percent), EF is the exposure frequency fixed at 30 meals/year for mussel and 365 meals/year for fish, ED is the exposure fixed at 70 years, BW is the human body weight fixed at $70 \mathrm{~kg}$, and AT is the average time of exposure fixed at 25,550 days (70 years).

Statistics: All linear regressions for calibration and calculating sample concentrations where preformed on built-in software of the Agilent ICP-MS. Standard deviations were calculated in Excel ${ }^{\circledR}$ and Student's t-test were performed manually.

\section{Results}

The analytical results for the 15 different water sampling sites are summarized in Figure 2. Student t-tests do not show significant differences between adjacent sampling sites for two metals of lowest concentration, cadmium, and tin, moving upstream from the mouth of the river. Upstream locations are below the detection limit of 1.0 $\mu \mathrm{g} / \mathrm{L}$ for lead (the lowest standard for the ICP-MS) while measureable and significantly different $(n=6, \alpha=0.05)$ concentrations are found within $75 \mathrm{~km}$ of the coast. Cobalt and chromium concentrations remain consistent and low through the reach of the river except at $171 \mathrm{~km}$ from the coast where each metal concentration has a slight spike in concentration that is significant $(8,0.05)$. Copper, the metal of highest concentration and the most variable throughout the river, significantly varies in concentration at river points $228 \mathrm{~km}, 123 \mathrm{~km}$ and $110 \mathrm{~km}$, and $45 \mathrm{~km}$ from the coast. While the primary focus of this investigation was to determine if metal concentrations in fish and mussel tissues from the river pose a health risk, it is worth noting that water metals concentrations along the river are all in the less then $10 \mu \mathrm{g} / \mathrm{L}$ range or less. How-

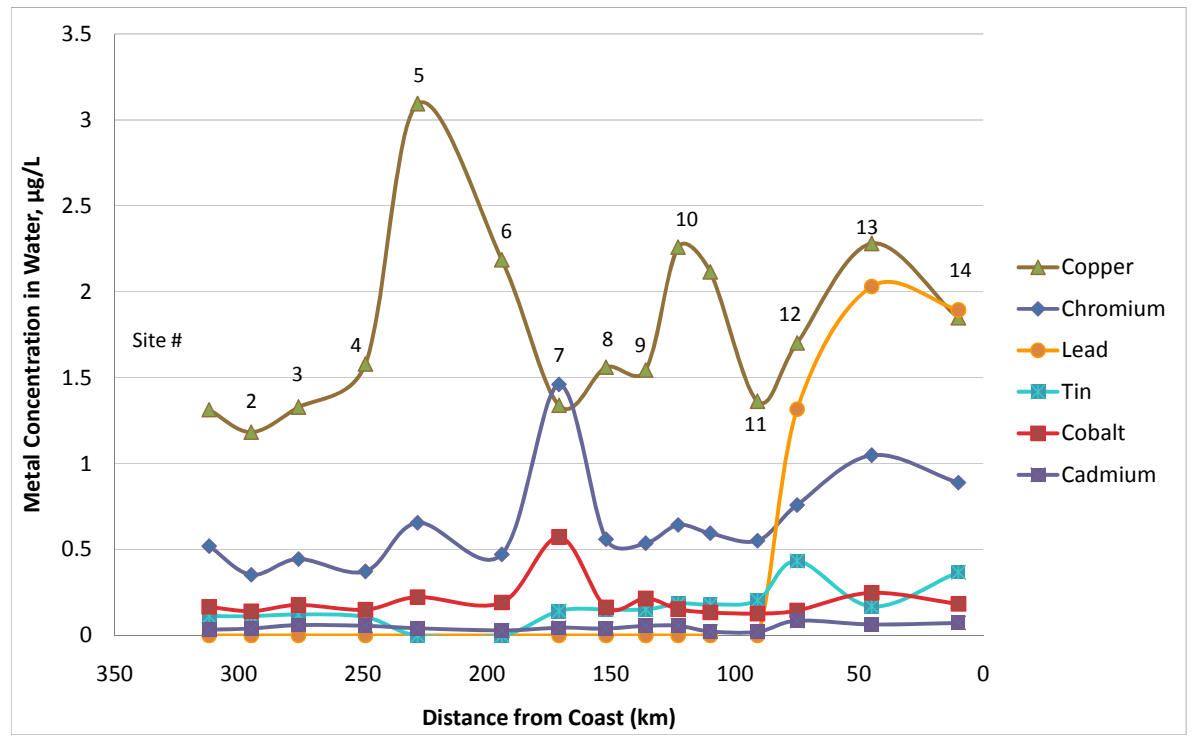

Figure 2. Average metal concentrations in the Klamath River water as a function of distance from the coast.

Table 2. Average spike recoveries for water, mussels, and fish.

\begin{tabular}{ccccccc}
\hline Sample Type & \multicolumn{2}{c}{ Average Spike Recovery $(\%)$} & & & \\
\hline & Chromium & Cobalt & Copper & Cadmium & Tin & Lead \\
\hline Water & 102 & 97.7 & 97.1 & 113 & 108 & 98.4 \\
Mussels & 99.2 & 94.1 & 91.8 & 79.2 & 81.1 & 44.8 \\
Salmon & 72.1 & 92.3 & 93.4 & 151 & 103 & 85.5 \\
Trout & 54.1 & 75.3 & 74.3 & 84.3 & 57.7 & 77.2 \\
Average & 81.8 & 89.9 & 89.2 & 107 & 87.4 & 76.5 \\
\hline
\end{tabular}


ever, as noted above some metals concentrations do vary significantly along the river.

A total of 81 mussels were analyzed for their trace metal content at sites 2-5 (from 295 to $228 \mathrm{~km}$ ) and 8-12 (from 152 to $91 \mathrm{~km}$, see Figure 1). Results for trace metals in mussels at each site are summarized in Figure 3. All lead measurements were below the relatively high 50 $\mathrm{g} / \mathrm{kg}$ detection limit in the raw mussel samples. All other metal concentrations vary from less then $10 \mu \mathrm{g} / \mathrm{kg}$ levels for tin to $2190 \mu \mathrm{g} / \mathrm{kg}$ for copper and when compared to the water concentrations, each metal clearly bioconcentrates in mussels. Mussel tissue samples in the headwaters have significantly higher concentrations of copper then those for other sites, specifically at $276 \mathrm{~km}$ from the coast. Significantly higher cadmium concentrations in mussle tissue were found at sites 11 and 12 (110 and 91 $\mathrm{km}$ from the coast). Significantly higher chromium levels were found at site 11 .

Chinook Salmon were sampled at sites 15 and 16 along the Kalmath River and trout were sampled from Indian Creek (site 7), the north fork of the Salmon River (site 17) and the south fork of the Salmon River (site 17). Data from these analyses are summarized in Table 3. All cadmium and tin concentrations were below detection limits in raw fish samples. Trout taken from Indian Creek tested highest for chromium, cobalt, and lead compared to trout taken from the North and South forks of the Salmon River. Trout from the north fork of the Salmon River tested comparatively high for copper. Statistical analyses (Student's t test) of the trout results indicated that: Chromium levels were significantly different between all sites (Indian Creek, the north fork of the Salmon River, and the South Fork of the Salmon River), cobalt concentrations were significantly different between Indian Creek and the north fork of the Salmon River and between the north and south fork of the Salmon River, copper concentrations were significantly different only between the north and south fork of the Salmon River, and lead concentrations were significantly different only between Indian Creek and the north fork of the Salmon River. No significant differences are expected for Salmon sampling sites because Chinook Salmon cease feeding once they return to the river to spawn and would likely not bioaccumulate trace metals from the river at any appreciable level.

\section{Discussion}

\subsection{Potential Sources of Trace Metals in Klamath Water}

All metals tested in this study steadily increase in concentration as sites approached the mouth of the Klamath River, except for the statistically significantly trends for lead, chromium, and cobalt noted in the results section.
This trend is most notably shown in chromium concentrations shown in Figure 2. Unfortunately, due to contamination in the ultra-trace acids used in sample presservation, very little can be concluded about trends in lead in water samples as sites approach the Californian coast. Samples only exceeded the lead detection limit in the lower $75 \mathrm{~km}$ of the river. This is most likely a result of the Trinity River that empties into the Klamath $80 \mathrm{~km}$ upriver. Another interesting trend, likely explained by the presence of this same stream confluence, is all metal concentrations increase from site 12 to site 13 ( 91 and 75 $\mathrm{km}$ from the coast). Site 13 is the first site tested below the Trinity River. The three sites closest to the termination of the river also tested highest or second highest for all metals analyzed. Shortly above the confluence on the Trinity is an EPA Superfund site named Celtor Chemical Works, which has been listed as contaminated due to the presence of lead, chromium, and copper, among other pollutants. Celtor Chemical Works is located on the Hoopa Indian reservation a small distance from the confluences of these two large rivers. It was deleted from the Superfund NPL in 2003, but may still be leaching metals from the site.

The highest concentrations found for both cadmium and tin were also found near sites 13-15 (75 and $10 \mathrm{~km}$ from the coast), while the highest concentration for lead was found at site $14,30 \mathrm{~km}$ further downriver. Relative maxima for both chromium and cobalt were found at site 7 (at $171 \mathrm{~km}$ ) just below Happy Camp, CA and the confluence of Indian Creek. Figure 2 shows this spike in chromium concentration at site 7 as compared to each site as the river gets closer to the Pacific Ocean. An EPA listed Superfund site called Grey Eagle Mine drains into Indian Creek. This site is not on the NPL and little has been done to prevent further leaching of known trace metals into the surrounding environment and surface water. Indian creek flows directly by the largest population concentration of Karuk Native Americans who reside in Happy Camp. It is possible that site 8 (at $152 \mathrm{~km}$ ) does not test high for either chromium or cobalt because these metals adsorb to particles and settle out of the water column. Copper tested highest at site 5 , but not significantly significant $(8,0.05)$, which lies 20 kilometers downriver of Quigley's Market, a local shopping stop with a boat ramp. It has been shown that both soil and water runoff from roads contains unnaturally high levels of copper and other trace metals $[24,25]$. Thus, it is possible that the boat ramp and continual presence of cars directly next to the river could be the point source of copper in the area.

\subsection{Potential Sources of Trace Metals in Freshwater Mussels}

As was the case with water samples, the concentration of 


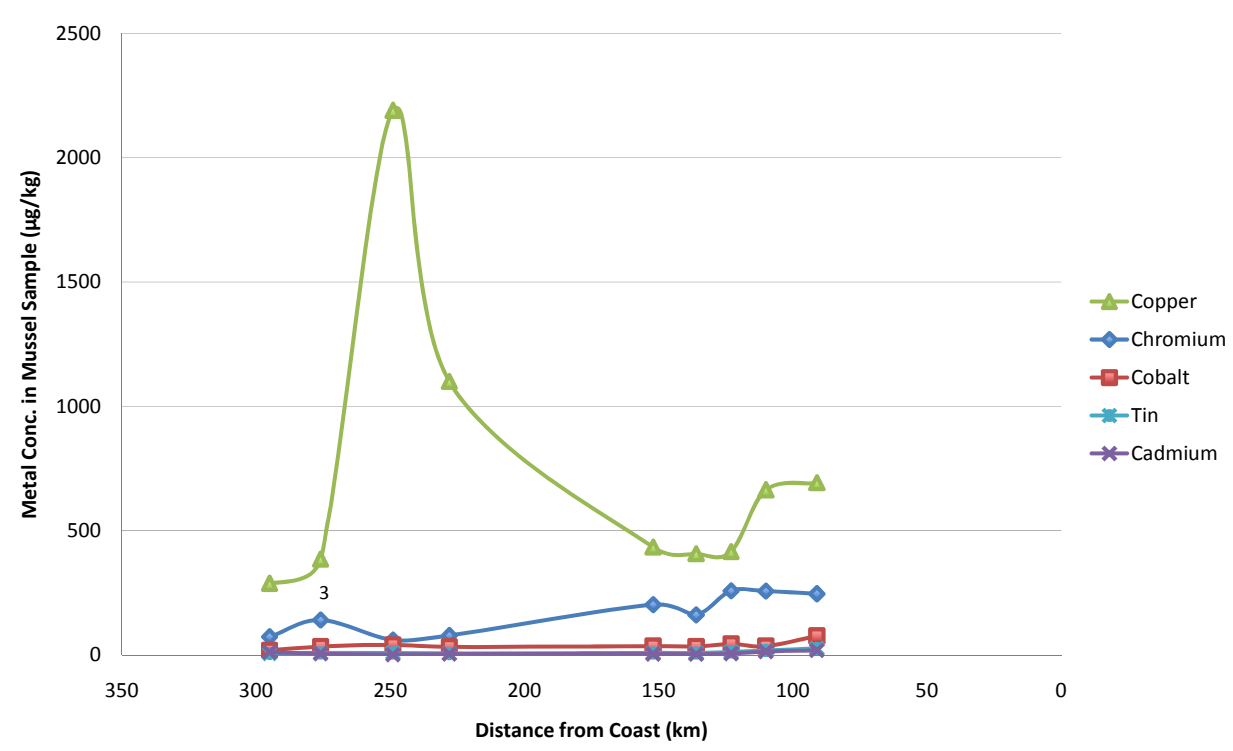

Figure 3. Average metal concentrations in mussel tissue as a function of distance from the coast.

Table 3. Summary of metal concentrations in fish.

\begin{tabular}{|c|c|c|c|c|c|c|c|c|c|c|c|}
\hline & \multirow[t]{3}{*}{ Sites } & \multirow[t]{3}{*}{ Samples Analyzed (n) } & \multicolumn{3}{|c|}{ Chromium } & \multicolumn{3}{|c|}{ Cobalt } & \multicolumn{3}{|c|}{ Copper } \\
\hline & & & \multicolumn{9}{|c|}{$\mu \mathrm{g} / \mathrm{kg}(\mathrm{ppb})$ in Fish } \\
\hline & & & Mean & Stdev & Range & Mean & Stdev & Range & Mean & Stdev & Range \\
\hline Salmon & 15,16 & 27 & 399 & 304 & $1623-177$ & 38 & 35 & $137-10$ & 684 & 173 & $1189-448$ \\
\hline Trout NS & 17 & 5 & 220 & 20 & $254-206$ & 46 & 17 & $75-35$ & 721 & 129 & $902-557$ \\
\hline Trout SS & 18 & 5 & 265 & 15 & $277-248$ & 82 & 22 & $107-53$ & 556 & 78 & $678-467$ \\
\hline \multirow[t]{4}{*}{ Trout IC } & 7 & 5 & 295 & 15 & $316-276$ & 86 & 24 & $126-64$ & 708 & 150 & $961-583$ \\
\hline & Sites & Samples Analyzed (n) & & Cadmium & & & Tin & & & Lead & \\
\hline & & & \multicolumn{9}{|c|}{$\mu \mathrm{g} / \mathrm{kg}(\mathrm{ppb})$ in Fish } \\
\hline & & & Mean & Stdev & Range & Mean & Stdev & Range & Mean & Stdev & Range \\
\hline Salmon & 15,16 & 27 & $<200$ & $\mathrm{n} / \mathrm{a}$ & $\mathrm{n} / \mathrm{a}$ & $<100$ & $\mathrm{n} / \mathrm{a}$ & $\mathrm{n} / \mathrm{a}$ & $<200$ & $\mathrm{n} / \mathrm{a}$ & $\mathrm{n} / \mathrm{a}$ \\
\hline Trout NS & 17 & 5 & $<100$ & $\mathrm{n} / \mathrm{a}$ & $\mathrm{n} / \mathrm{a}$ & $<20$ & $\mathrm{n} / \mathrm{a}$ & $\mathrm{n} / \mathrm{a}$ & $<200$ & $\mathrm{n} / \mathrm{a}$ & $\mathrm{n} / \mathrm{a}$ \\
\hline Trout SS & 18 & 5 & $<100$ & $\mathrm{n} / \mathrm{a}$ & $\mathrm{n} / \mathrm{a}$ & $<20$ & $\mathrm{n} / \mathrm{a}$ & $\mathrm{n} / \mathrm{a}$ & $<200$ & $\mathrm{n} / \mathrm{a}$ & $\mathrm{n} / \mathrm{a}$ \\
\hline Trout IC & 7 & 5 & $<100$ & $\mathrm{n} / \mathrm{a}$ & $\mathrm{n} / \mathrm{a}$ & $<20$ & $\mathrm{n} / \mathrm{a}$ & $\mathrm{n} / \mathrm{a}$ & $<200$ & $\mathrm{n} / \mathrm{a}$ & $\mathrm{n} / \mathrm{a}$ \\
\hline
\end{tabular}

NS, SS, and IC refer to North Salmon River, South Salmon River, and Indian Creek respectively; n/a: not applicable due to instrumentation limitations for this study.

all metals in mussel samples increased downstream. For all sites tested measurements of lead were below the 45.5 $\mu \mathrm{g} / \mathrm{kg}$ detection limit in raw mussel samples, thus for some metals the detection limit was used to estimate the upper limit of risk. Considering the known toxicity of these elements this is a positive outcome. For site 12, the averages from cobalt and tin were not significantly higher than any other site on the river. The high standard deviations in these cobalt and tin is possibly due to a single mussel sample preferentially bioaccumulating specific elements. Cadmium levels were significantly higher at site $12,91 \mathrm{~km}$ from the mouth of the river, than anywhere else except site 11, $19 \mathrm{~km}$ further upriver (Figure 3). Site 12 is located next to a small town called Orleans, CA that may serve as a source for cobalt, tin, and cadmium. Copper was found at distinctly higher levels at 
sites 4 and 5, next to Quigley's Market. Once again this may be a result of Quigley's Market being a high use area for cars close to the river. Chromium levels were highest at site 11 near Somes Bar California. There are no creeks that flow into the Klamath River immediately near this site, therefore the source of this chromium is unknown.

\subsection{Accumulation of Trace Metals in Salmon and Trout}

Salmon samples were collected to determine if there are any harmful ingestion levels of trace metals present in the fish based on risk assessment. All salmon tested below detection limits for cadmium and tin in raw fish samples $(2.0 \mu \mathrm{g} / \mathrm{kg}$ and $20 . \mu \mathrm{g} / \mathrm{kg}$, respectively). Trace metals concentrations in salmon muscle tissue varied depending on the individual fish as noted by the high standard deviation in Table 3. Possible reasons for this may include variety of feeding area (areas near harbors contain more trace metals in the water than further out at sea) or fish age and size (fish sample age and size were not recorded).

In addition to evaluating their contamination as traditional foods, Rainbow Trout were analyzed in this study for two purposes. First, was to test if certain trace metals were accumulating more in trout from Indian Creek (TroutIC) as compared to trout from the North and South Fork of the Salmon River (TroutNS and TroutSS respecttively). Second, was to determine if there was a significant difference between trout, which spend their whole lives living in the waters of the Klamath River, and salmon, which spend a majority living out in the ocean. Data summaries are give in Table $\mathbf{3}$ and Student's t-test on TroutIC samples showed significantly higher concentrations of chromium and cobalt than samples from TroutNS $(5,0.05)$. TroutIC samples also demonstrated significantly higher $(5,0.05)$ levels of cobalt than samples from TroutSS. TroutIC fish are also almost signifi- cantly higher $(5,0.10)$ in lead than fish from TroutSS. Individual variations in age for the different fish from the three different sites may account for the standard deviations. Oceanic salmon showed significantly higher chromium and lower cobalt as compared to all freshwater fish.

\subsection{Risk Assessment Calculations}

Again, the primary focus of this investigation was to determine if water, mussel, or fish pose a health risk due to metal contamination. Both federal and state organizations (EPA, and the Federal-State toxicology and risk analysis Committee (FSTRAC)) have established maximum contaminant levels (MCLs) in water for all metals analyzed in this study [26,27]. At no site tested in this study did water samples exceed MCLs mandated by either state or federal governments (refer to Table 4). A person may drink 1.5 L of water from the Klamath per day for 70 years and never be exposed to any significant health risk from trace metals.

Risk calculations were performed on the highest individual samples of mussel and fish comparing them to minimal risk levels (MRL) established by the agency for toxic substances and disease registry (ATSDR) [28-34]. The highest recorded concentrations were used in these calculations instead of average concentrations to see of any individual fish or shellfish were approaching unsafe levels. Findings, shown in Table 5, for mussels indicate that samples tested in this study contain levels of trace metals safe for human consumption including at traditional levels of consumption. Even when calculating lifetime exposure, estimated at 70 years, consuming $0.43 \mathrm{~kg}$ of shellfish per meal, 365 meals a year, there is still no single mussel that exhibits unsafe levels in any metal. Findings for fish from the Klamath River Basin were similar. When risk assessment was repeated for fish, this time using historical Karuk diet levels $(0.5 \mathrm{~kg} /$ day and 365 days/year; [8]) cadmium levels only slightly violated

Table 4. Risk calculation for trace metal consumption in water and fish.

\begin{tabular}{|c|c|c|c|c|c|c|}
\hline Metal & Known Carcinogen & $\begin{array}{l}\text { CM (max) Concentration } \\
\text { in Fish }(\mu \mathrm{g} / \mathrm{kg})\end{array}$ & $\begin{array}{c}\text { Intake }(\mu \mathrm{g} / \mathrm{kg} \cdot \text { day }) \\
\text { EPA Est. }\end{array}$ & $\begin{array}{c}\text { Intake }(\mu \mathrm{g} / \mathrm{kg} \cdot \text { day }) \\
\text { OR Est. }\end{array}$ & $\begin{array}{l}\text { ATSDR MRL } \\
(\mu \mathrm{g} / \mathrm{kg} \cdot \text { day })\end{array}$ & $\begin{array}{l}\text { Violates the MRL? } \\
\text { (EPA/OR) }\end{array}$ \\
\hline Chromium & Yes & 398 & 0.0260 & 1.00 & 5 & No \\
\hline Cobalt & Yes & 137 & 0.0090 & 0.34 & 10 & No \\
\hline Copper & No & 1189 & 0.0778 & 2.97 & 10 & No \\
\hline Cadmium ${ }^{*}$ & Yes & 2 & 0.0001 & 0.01 & 0.5 & No \\
\hline $\operatorname{Tin}^{*}$ & No & 20 & 0.0013 & 0.05 & 300 & No \\
\hline Lead $^{*}$ & Yes & 200 & 0.0131 & 0.50 & $\mathrm{n} / \mathrm{a}$ & $\mathrm{n} / \mathrm{a}$ \\
\hline
\end{tabular}

*Estimated risk levels due to detection limits in instruments; Ingestion rate for EPA estimates are $0.00458 \mathrm{~kg} / \mathrm{meal}$, ingestion rate for Oregon estimates are $0.175 \mathrm{~kg} / \mathrm{meal}$, fraction of intake from polluted source equal 1.00 , exposure frequency was 365 meals/yr, exposure duration was 70 . Years, body weight was $70.0 \mathrm{~kg}$, and the average time was 25,550 days (70 years). $\mathrm{n} / \mathrm{a}$ : Pb MRLs were not derived because a clear threshold for some of the more sensitive effects in humans has not been identified. 
Table 5. Risk calculation for trace metal consumption in mussels.

\begin{tabular}{|c|c|c|c|c|c|}
\hline Metal & Known Carcinogen & $\begin{array}{l}\text { CM (max) Concentration } \\
\text { in Mussel }(\mu \mathrm{g} / \mathrm{kg})\end{array}$ & Intake $(\mu \mathrm{g} / \mathrm{kg} \cdot$ day $)$ & $\begin{array}{l}\text { ATSDR MRL } \\
(\mu \mathrm{g} / \mathrm{kg} \cdot \text { day })\end{array}$ & Violates the MRL? \\
\hline $\mathrm{Cr}$ & Yes & 739.2 & 0.0373 & 5 & No \\
\hline Co & Yes & 69.8 & 0.0035 & 10 & No \\
\hline $\mathrm{Cu}$ & No & 7575.0 & 0.3825 & 10 & No \\
\hline $\mathrm{Cd}$ & Yes & 33.9 & 0.0017 & 0.5 & No \\
\hline $\mathrm{Sn}$ & No & 165.9 & 0.0084 & 300 & No \\
\hline $\mathrm{Hg}$ & No & 50. & 0.0023 & 2 & No \\
\hline $\mathrm{Pb}^{*}$ & Yes & 50. & 0.0023 & $\mathrm{n} / \mathrm{a}$ & $\mathrm{n} / \mathrm{a}$ \\
\hline
\end{tabular}

${ }^{*} \mathrm{~Pb}$ MRLs were not derived because a clear threshold for some of the more sensitive effects in humans has not been identified. Site specific lead blood (PbB) levels are used instead of MRLs. Ingestion rates are $0.0043 \mathrm{~kg} / \mathrm{meal}$, fraction of intake from polluted source equal 1.00 , exposure frequency was $30 \mathrm{meals} / \mathrm{yr}$, exposure duration was 70 years, body weight was $70.0 \mathrm{~kg}$, and the average time was 25,550 days (70 years). n/a: Pb MRLs were not derived because a clear threshold for some of the more sensitive effects in humans has not been identified.

the ATSDR limit, by $0.2 \mu \mathrm{g} / \mathrm{kg}$-day. Once again, this finding should cause no immediate alarm as all fish samples tested below the cadmium instrument detection limit and the detection limit was used for risk assessment calculations. One limitation of this investigation is the absence of mercury data due to the $\mathrm{ng} / \mathrm{L}$ levels is the digestion acids that compounded to $\mu \mathrm{g} / \mathrm{kg}$ calculated minimum detection levels in the tissue samples when correcting for the dilution factors. A more exhaustive study should therefore be conducted on the mercury content of fish along the Klamath River. Our results indicate that water, fish, and freshwater mussels in the Klamath River contain levels of trace metals (specifically chromium, cobalt, copper, cadmium, tin and lead) safe for human consumption.

\section{Acknowledgements}

We thank the Karuk Department of Natural Resources, especially Ron Reed and Toz Soto for assistance with project design and support in collecting and shipping samples. Emily Davis, Aaron David and Sam "Salmon" Norgaard also provided helpful support in the field. This document also benefited from reviews and technical assistance from Amy Molitor. Project funding came from a Louis B. Perry award at Whitman College.

\section{REFERENCES}

[1] G. W. Hewes, "Indian Fisheries Productivity in PreContact Times in the Pacific Salmon Area," Northwest Anthropological Research Notes, Vol. 7, No. 3, 1973, pp. 133-155.

[2] A. E. McEvoy, "The Fisherman's Problem: Ecology and Law in the California Fisheries 1850-1980," Cambridge University Press, New York, 1986. doi:10.1017/CBO9780511583681

[3] H. Doremus and D. Tarlock, "Water War in the Klamath
Basin: Macho Law, Combat Biology, and Dirty Politics," Island Press, Washington DC, 2008.

[4] H. Gosnell and E. C. Kelly, "Peace on the River? Social-Ecological Restoration and Large Dam Removal in the Klamath Basin, USA," Water Alternatives, Vol. 3, No. 2, 2010, pp. 361-383.

[5] C. Mooney, "The Republican War on Science," Basic Books, New York, 2005.

[6] D. N. Allen, "The Klamath Hydroelectric Settlement Agreement: Federal Law, Local Compromise, and the Largest Dam Removal Project in History," Hastings West-Northwest Journal of Environmental Law and Policy, Vol. 16, No. 2, 2010, pp. 427-468.

[7] J. F. Salter, "White Paper on Behalf of the Karuk Tribe of California: A Context Statement Concerning the Effect of Iron Gate Dam on Traditional Resource Uses and Cultural Patterns of the Karuk People Within the Klamath River Corridor," 2003.

http://elibrary.ferc.gov/idmws/docket_sheet.asp

[8] K. Norgaard, "The Effects of Altered Diet on the Health of the Karuk People," Karuk Tribe of California, Orleans, 2005.

[9] T. K. King, "First Salmon the Klamath Cultural Riverscape and the Klamath Hydroelctric Project Klamath River Intertribal Fish and Water Commission," 2004. http://elibrary.ferc.gov/idmws/File_list.asp?document_id $=4205564$

[10] R. Kanz, "Final Report to the US Environmental Protection Agency on Cyanotoxin Accumulation in Fish and Freshwater Mussels of the Klamath River Water Quality Cooperative Agreement CP 96941301-2,” 2008. http://www.waterrights.ca.gov/FERC/ceqa_projects.html

[11] M. P. Hunerlach, J. J. Rytuba and C. N. Alpers, "Mercury Contamination from Hydraulic Placer-Gold Mining in the Dutch Flat Mining District, California," USGS WaterResources Investigations Report 99-4018B, 1999, pp. 179189.

[12] B. C. Kelly, M. G. Ikonomou, D. A. Higgs, J. Oakes and C. Dubetz, "Mercury and Other Trace Elements in Farmed 
and Wild Salmon from British Columbia, Canada," Environmental Toxicology and Chemistry, Vol. 27, No. 6, 2008, pp. 1361-1370. doi:10.1897/07-527.1

[13] R. L. Idzelis, V. Kesminas, G. Svecevicius and A. Venslovas, "Experimental Investigation of Heavy Metal Accumulation in Tissues of Stone Loach Noemacheilus barbatulus (L.) and Rainbow Trout Oncorhynchus mykiss (Walbaum) Exposed to a Model Mixture (Cu, Zn, Ni, Chromium, $\mathrm{Pb}$, Cd)," Journal of Environmental Engineering and Landscape Management, Vol. 18, No. 2, 2010, pp. 111-117.

[14] Anonymous, "Marine Pollution Bulletin (MPB). Mercurial Tuna: Study Explores Sources of Mercury to Ocean Fish," Marine Pollution Bulletin, Vol. 60, No. 4, 2010, pp. 489-492. doi:10.1016/j.marpolbul.2010.03.001

[15] M. G. Ikonomou, D. A. Higgs, M. Gibbs, J. Oakes, B. Skura, S. McKinley, S. K. Balfry, S. Jones, R. Withler and C. Dubetz, "Flesh Quality of Market-Sized Farmed and Wild British Columbia Salmon," Environmental Science and Technology, Vol. 41, No. 2, 2007, pp. 437-443. doi:10.1021/es060409+

[16] T. J. Naimo, "A Review of the Effects of Heavy Metals on Freshwater Mussels," Ecotoxicology, Vol. 4, No. 6, 1995, pp. 341-362. doi:10.1007/BF00118870

[17] Environmental Protection Agency (EPA), "Grey Eagle Mine," 2005.

http://yosemite.epa.gov/r9/sfund/r9sfdocw.nsf/BySite/gre $\mathrm{y} \% 20$ eagle\%20mine? OpenDocument

[18] Environmental Protection Agency (EPA), "Celtor Chemical Works," 2010.

http://yosemite.epa.gov/r9/sfund/r9sfdocw.nsf/viewbyepa id/cad 980638860?opendocument

[19] K. J. Buhl and S. J. Hamilton, “Comparative Toxicology of Inorganic Contaminants Released by Placer Mining to Early Life Stages of Salmonids," Ecotoxicology and Environmental Safety, Vol. 20, No. 3, 1990, pp. 325-342. doi:10.1016/0147-6513(90)90010-3

[20] G. A. Van den Berg, G. G. A. Meijers, L. M. Heijdt and J. J. G. Zwolsman, "Dredging-Related Mobilization of Trace Metals: A Case Study in the Netherlands," Water Research, Vol. 35, No. 8, 2001, pp. 1979-1986. doi:10.1016/S0043-1354(00)00452-8

[21] L. H. Hedge, N. A. Knott and E. L. Johnston, "Dredging Related Metal Bioaccumulation in Oysters," Marine Pollution Bulletin, Vol. 58, No. 6, 2009, pp. 832-840. doi:10.1016/j.marpolbul.2009.01.020

[22] ASTM Standard E2455-06, "Standard Guide for Con- ducting Laboratory Toxicity Tests with Freshwater Mussels," ASTM International, West Conshohocken, 2006. doi:10.1520/E2455-06 www.astm.org

[23] J. F. Louvar and B. D. Louvar, "Health and Environmental Risk Analysis: Fundamentals with Applications," Prentice Hall, Upper Saddle River, 1998.

[24] C. Aydinalp, "The Status of Some Selected Heavy Metals in Roadside Soils of Bursa Province, Turkey," Environmental Engineering and Management Journal, Vol. 9, No. 4, 2010, pp. 559-563.

[25] N. C. Munksgaard and B. G. Lottermoser, "Mobility and Potential Bioavailability of Traffic-Derived Trace Metals in a 'Wet-Dry' Tropical Region, Northern Australia," Environmental Earth Sciences, Vol. 60, No. 7, 2010, pp. 1447-1458. doi:10.1007/s12665-009-0280-5

[26] Federal-State Toxicology and Risk Analysis Committee (FSTRAC), "Summary of State and Federal Drinking Water Standards and Guidelines," USEPA/Office of Water (EPA\# 570R90019), 1993.

[27] Environmental Protection Agency (EPA), "List of Contaminants \& their MCLs," 2009. http://www.epa.gov/safewater/contaminants/

[28] Agency for Toxic Substances and Disease Registry (ATSDR), "Toxicological Profile for Cadmium," Atlanta, 2009. http://www.atsdr.cdc.gov/toxprofiles/ index.asp

[29] Agency for Toxic Substances and Disease Registry (ATSDR), "Toxicological Profile for Chromium," Atlanta, 2009. http://www.atsdr.cdc.gov/ toxprofiles/index.asp

[30] Agency for Toxic Substances and Disease Registry (ATSDR), "Toxicological Profile for Cobalt," Atlanta, 2009. http://www.atsdr.cdc.gov/toxprofiles/ index.asp

[31] Agency for Toxic Substances and Disease Registry (ATSDR), "Toxicological Profile for Copper," Atlanta, 2009. http://www.atsdr.cdc.gov/toxprofiles/ index.asp

[32] Agency for Toxic Substances and Disease Registry (ATSDR), "Toxicological Profile for Lead," Atlanta, 2009. http://www.atsdr.cdc.gov/toxprofiles/ index.asp

[33] Agency for Toxic Substances and Disease Registry (ATSDR), "Toxicological Profile for Mercury," Atlanta, 2009. http://www.atsdr.cdc.gov/toxprofiles/ index.asp

[34] Agency for Toxic Substances and Disease Registry (ATSDR), "Toxicological Profile for Tin," Atlanta, 2009. http://www.atsdr.cdc.gov/toxprofiles/ index.asp 